\title{
A New Species of Heterothrips (Thysanoptera: Heterothripidae) from Puerto Rico
}

\author{
Silverio Medina Gaud
}

\section{INTRODUCTION}

Heterothrips oneillae is a new species of the Puerto Rican Heterothrips fauna discovered about 4 years ago. Since then several specimens have been obtained from subsequent collections. This is the third species of Heterothrips described from our Island.

\section{Heterothrips oneillae NEW SPECIES}

Female (macropterous). Length about 1,090 to $1,420 \mu$ in distended specimens. Color light-brown to brown, darker at sides of head, thorax, and abdomen; all tarsi, basal and apical third of foretibia, middletibia, and hindtibia yellow, all femora slightly yellow on inner apical part; antennal segments I light-brown, II and V to IX brown, III and IV yellow with brown tinge on apical half, red-orange tinge on apical part of II and IV, forewings brown, with pale broad band extended from first costal setae, ending about second costal setae on anterior part, on posterior, at first setae on hindvein; hindwing pale with dark median vein. Internal pigmentation red around ocelli, scattered on head, very intense on pro- and metathorax.

Head wider than long; shape, eyes, ocelli, and reticulations normal. Antennal segment III very long and slender, similar to $H$. analis Hood, IV shorter than III; a ring of sensoria on antennal segment III and IV narrow, reduced to a single row of more or less round areas (about 12) on dorsum irregularly placed across the band (fig. 1,A.).

Two pairs of simple sense cones on segment $\mathrm{V}$, and one pair on VI. Length of antennal segments in microns: I, 20; II, 30; III, 70; IV, 49; V, 30; VI, 32 ; VII, 12; VIII, 13; IX, 11. Maxillary palpi 3-segmented, labial palpi 2segmented.

Pronotum (fig. 2,A) with small scattered setae (about 34), reticulations heavy on the entire surface, irregular, most at right angles to the body axis, some striations joining irregularly. Reticulations under oil immersion resemble stipple lines: Black and white dots over a dark line. Meso- and metanotum and wings normal to the genus. Forewing with 25 to 35 setae on forevein and 18 to 25 setae on hindvein. Claw present on foretarsi.

1 Assistant Entomologist, Agricultural Experiment Station, University of Puerto Rico, Rín Piedras, P.R. The writer wishes to express his acknowledgement to Miss Kellie O'Neill of the Division of Insect Identification and Parasite Introduction of the U.S. Department of Agriculture, for having pointed out to the author this new species of thrips. 

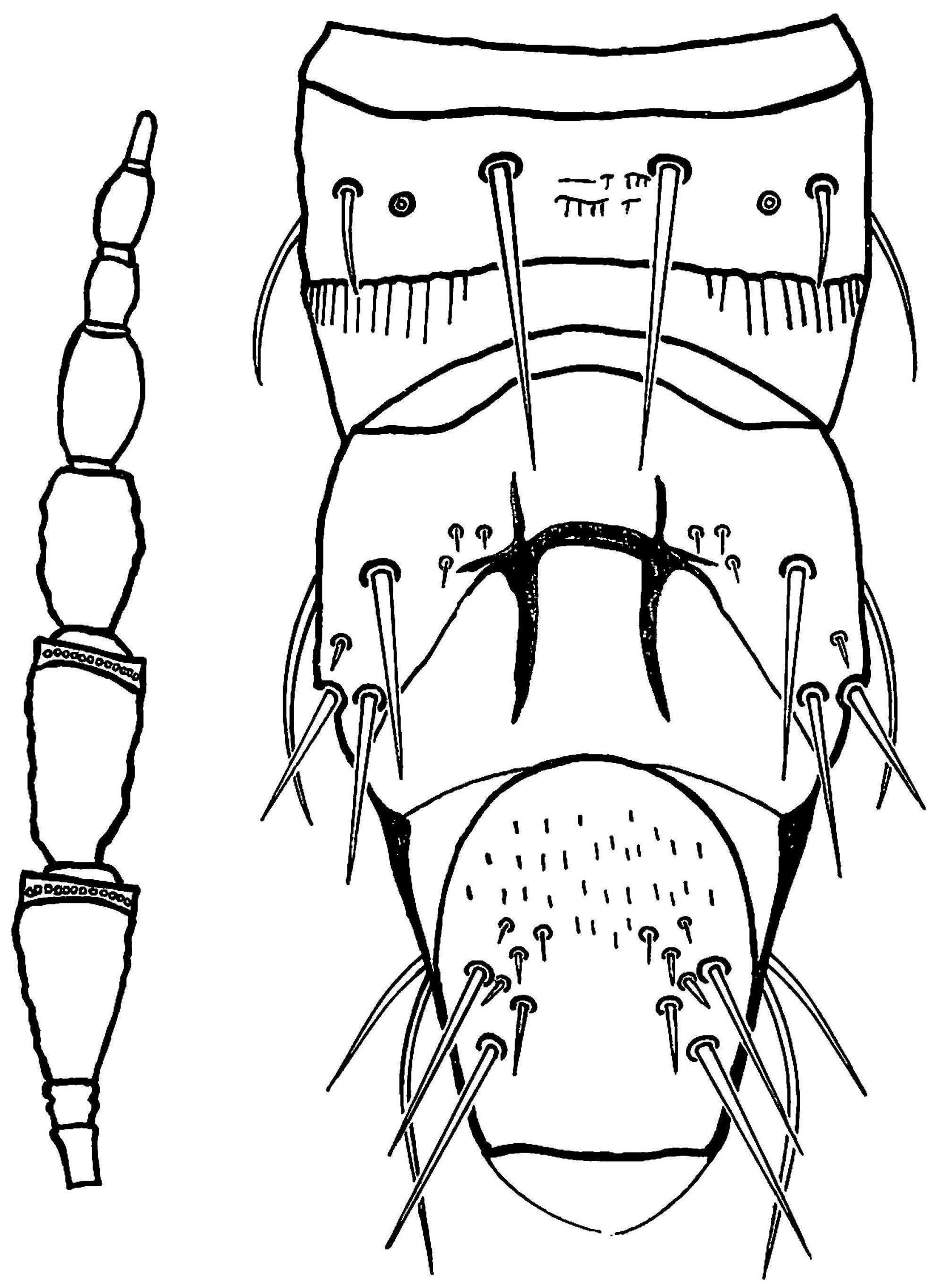

A

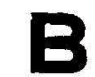

Fig. 1.-Heterothrips oneillae n. sp.: A, female (paratype) antennal segments III-IX; B, male (allotype), dorsal aspect of abdominal segments VIII-X. 

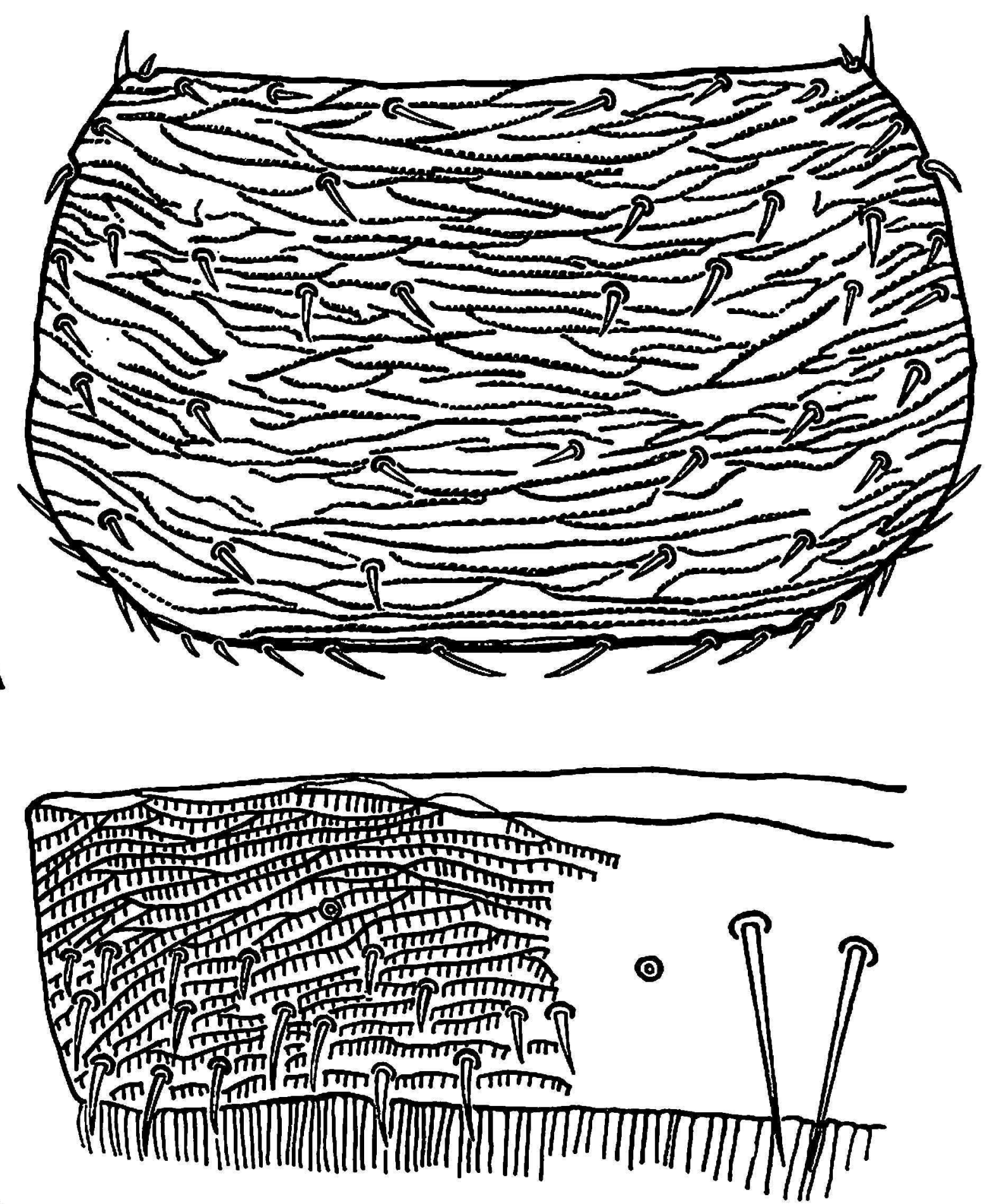

$\mathbf{B}$

Fia. 2.-Heterothrips oneillae n. sp.: A, female (holotype), pronotum; B, female (holotype) abdominal tergum VI, left side.

Abdomen with lateral reticulations heavy with regularly spaced microtrichia, fringe of setae on posterior margins not joined at bases to form plates, complete fringe on sternites made up of long slender setae, terminal segment short; fringe complete dorsally on segments VI (fig. 2,B) and VII and VIII only. 
Male (macropterous). Length about 790-1,120 $\mu$, in partly to completely distended specimens. Similar to female, but smaller. Forewing, as based on 9 individuals, each with forevein bearing 19 to 29 setae, hindvein bearing 16 to 21 setae. Glandular areas absent. Chitinous processes on dorsum of segment IX present, very dark in color and strong (fig. 1,B).

Measurements of holotype (female) in microns: Length about 1,2:30; head length 100, width across eyes 130 , greatest width across cheeks 140 , least width near base 125; prothorax median length of pronotum 110, greatest width (inclusive of coxac), 200; width across anterior angles 150; metathorax, greatest width 250; abdomen greatest width 340; antennal segments length: I, 20; II, 30; III, 70; IV , 49; V, 30; VI, 32; VII, 12; VIII, 13 ; IX, 11.

Measurements of allotype (male) in microns: Length about 980; head length 100 ; width across eyes 130 ; greatest width across cheeks 125 ; least width near base 120; prothorax median length of pronotum 110, greatest width (inclusive of coxae) 170 ; width across anterior angles 125, meta(horax greatest width 190; abdomen greatest width 155 ; antennal segments length; I, 10; II, 20; III, 60; IV, 50; V, 333; VI, 38; VII, 15; VIII, 18 ; IX, 10.

Described from eight females and nine males with the following data: Holotype (female) and two females and two males paratypes Nos. 137-59, collected at El Yunque, Lucquillo, P.R., on Psidium guajara L. flowers, on April 2:3, 1959, by Silverio Medina Gaud. The allotype (male), No. 16159, collected at Río Ahajo Forest, Utuado, P.R., on January 19, 1959, on the same host, by the same collector. One male paratype No. 12-59, collected at Santa Isabel-1'once Road, P.R. on Lippia nodiflora (L.) Michx. flowers, on February 12, 1959, by Silverio Medina Gaud and Gaspar Rivera Mercado. One female and two male paratypes Nos. 159-59. and four female and three male paratypes, Nos. 51-(i1, collected at Doña Juana liorest, Villalba, P.R. on Psidium guajara flowers on June 18, 1959 and June 20, 1961, by Silverio Medina Gaud. All types are kept in Insect Collection at the Agricultural Experiment Station at Río l'iedras.

This species is apparently similar to $H$. analis which is known to me solely from the description of Hood in $1915(2)^{2}$. On the hasis of characteristies of the male and female at least, the two seem to be easily distinguishable. In $H$. analis, according to Ilood, the antemal segments III-V are pale grayish yellow and VI paler basally, while in $H$. oneillae 11 . sp. only the III and IV are yellow, others are brown, the not um in $H$. analis is with few inconspicuous bristles, while $H$. oneillae 11 . sp. has about 34 conspicuous bristles. The males are very similar but can be distinguished easily by the examination of the terminal abdominal segments. In $H$. oneillae $n$. sp. the

"Italic numbers in parentheses refer to Jiterature Cited on p. 168. 
fingerlike or chitinous processes are longer and differently shaped as compared with Hood's drawing of $H$. analis.

This species belongs to group I of Moulton's 1932 (4) and Bailey's 1954 (1) keys to Heterothrips. In the key to Puerto Rican Heterothrips by Medina Gaud, 1961 (s), it can be separated from $H$. sericatus Hood by the coloration of the forewing and antennal segment $V$.

This species is named in honor of Miss Kellie O'Neill of the Division of Insect Identification and Parasite Introduction of the U.S. Department of Agriculture, in recognition for her great dedication to the studies of the Thysanoptera.

\section{SUMMARY}

Heterothrips oneillae, a new thrips species, is described and illustrated from Puerto Rico.

\section{RESUMEN}

Se describe y se ilustra una nueva especie de trípido, Heterothrips oneillae, de Puerto Rico.

\section{LITERATURE CITED}

1. Bailey, S. F., A review of the genus Helerolhips Hood (Thysanoptera: Heterpthripidae) in North America, with descriptions of two new species, Ann. Ent. Soc. Amer. 47 (4) 614-35, 1954.

2. Hood, J. D., Descriptions of new American Thysanoptera, Insecutor Insritiac Mentrus. $3(1-4)$ 1-40, 1915.

3. Medina-(Gaud, Silverio, The Thysanoptern of Puerto Rico, Agr. Exp. Sta., Univ. P.R., Río Piedras, P.R., Tech. Paper 32, pp. 1-160, 1961.

4. Moulton, D., The Thysanoptera of South America (I) Rev. de Ent. 2 451-84, 1932. 